\title{
HISTORY INFORMATION'S ARE INDISPENSABLE IN DEVELOPMENTAL ASSESSMENT OF CHILDREN
}

\author{
Aneta Demerdzieva ${ }^{1}$ and Nada Pop-Jordanova ${ }^{2}$ \\ ${ }^{1}$ Acibadem Sistina Hospital, Skopje, R. N. Macedonia \\ ${ }^{2}$ Macedonian Academy of Sciences and Arts, Skopje, R. N. Macedonia
}

Corresponding author: Nada Pop-Jordanova, Bul Krste Misirkov br.2, P.O.Box 428, 1000 Skopje, North Macedonia, e-mail: popjordanova.nadica@gmail.com

\section{ABSTRACT}

For achieving the good health and wellbeing for all children, the main role of pediatrician and other health care professionals is to follow their development.

We implemented developmental monitoring for 465 children at the age of 12 - 60 months, in the period of 4 years (2016 - 2019), using standard algorithm in which start is always with child history. It should be comprehensive, and must include a detailed prenatal, perinatal, and postnatal history.

Obtained results showed that $16.13 \%$ of participants have some serious illness in family history, and the same percentage (16.13\%) manifested serious perinatal problems which imposed the support in intensive care unit. Breastfeed are 49,46\% of children. Only 7,53\% are not completely vaccinated.

About the parameters for the development, we obtained that $11,83 \%$ were not walking at the time of the assessment, and $65,81 \%$ were not speaking. Toilet control was negative, and in 75,27 \% they still were wearing diapers.

Allergic manifestations at the time when the assessment was done is present in $8,60 \%$. Finally, serious illness in child past history was positive in $19.35 \%$ of evaluated sample.

We concluded that a good history is needed and indispensable in the assessment process, particularly when exogenous causes are identified as the risk for the developmental delay. Obtained positive answers are directory for further investigation as well to correlate risk-consequences relationship.

Keywords: development, children, assessment, history

\section{INTRODUCTION}

For achieving the good health and wellbeing of all children the main role of pediatrician and health care professionals is to follow their development. However, together with pediatricians, all others health care professionals have to promote desired social, developmental and health outcomes of infants, children, and adolescents. Research about the development has also been stimulated by social pressure which impose to improve the lives of all children in the world. In the past, pediatrician's interest in improving children's health required just an understanding of physical growth and nutrition. Today, we need knowledge not just for physical examination but either for appropriate developmental assessment, including personality and social development. Our mission must be to increase family knowledge, skills, and participation in health promotion and disease prevention activities. That's why early identification of developmental delay is not 
only responsibility but either obligation of all health care professionals, especially pediatricians. According to Policy Statement for Identifying Infants and Young Children with Developmental Disorders in the Medical Home: An Algorithm for Developmental Surveillance and Screening from American Academy of Pediatrics, developmental surveillance must be incorporated in every well-child preventive care visit [1].

Recent studies showed that as many as 1 in 4 children in the United States, ages 0 to 5, are at moderate or high risk for developmental, behavioral, or social delays [2]. Do we think that we are different? In US young children who live-in low-income families are even more likely to have a developmental delay [3]. Unfortunately, in our country many families still are with low income. So, we have to be aware with this very serious problem. Especially if we know that developmental delay can lead to behavior problems and poor academic achievement further [4].

Surveillance of all children is a continuous process in which health care professionals skillfully observe children, listen about parental concerns, make adequate observations of children, and share opinions and concerns with other relevant professionals. Surveillance include developmental screening and use of a standardized tool to detect a particular disease state. Universal screening is performed on all patients at certain ages. Selective screening is performed on patients for whom a risk assessment suggests concern. Pediatricians have to complete anamnestic and physical examination in order to find all possible medical reasons for developmental delay, especially those which need early treatment.

Our approach to developmental monitoring incudes several steps. The picture below presents steps needed in the developmental evaluation (Fig.1).

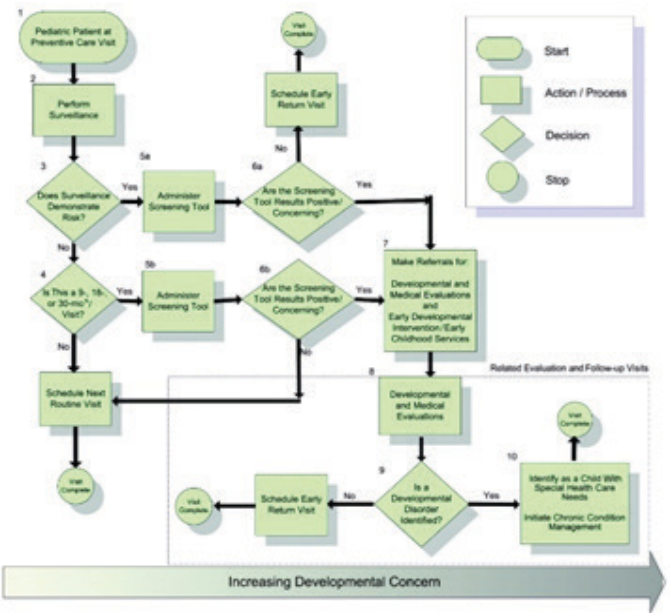

Fig. 1. Steps proposed for developmental assessment (Downloaded from www.aappublications.org/news by guest on April 1, 2020)
Parents usually came to medical visit with some level of concern for child development - sometimes real, according to the very specific symptoms, and sometimes just because of some family history (other disabled child in family) or concerns raised by the primary care pediatrician. Developmental concerns should be included as one of several health topics addressed at each pediatric preventive care visit throughout the first 5 years of life (1). Asking parents, especially about their child's behavior, can yield valuable information regarding development, because parents do not necessarily differentiate between behavior and development, and developmental delays is often manifested through behavior. But it is obvious that the absence of parental concern does not preclude the possibility of serious developmental delays [5].

The start of the pediatric assessment is the very careful history - family history, information's about pregnancy and delivery, immunizations, vitamin D prophylaxes, past diseases, allergic predispositions, social status of family etc. Asking for specific information like risk factors: maternal or parental age, premature birth, family members with language impairment, learning or intellectual disabilities, autism spectrum disorder, motor disorder, ADHD, history of deafness, genetic or metabolic disorders, retinal dysplasia, glaucoma, and so on is very important. Second step is very careful examination, in order to find same kind of organ dysfunction. Special attention must be pointed if child has chronic respiratory or allergic illness, recurrent otitis, head trauma, or sleep problem. Special attention to growth parameters, head shape and circumference, possible facial or body dysmorphic signs, vascular markings, testicular volume and signs of neurocutaneous disorders must be done. Additionally, neurological examination is crucial, especially knowing that children with developmental disabilities have very high rate of seizure disorder, structural MRI abnormalities (like frontal atrophy). Neuropsychological correlates include some level of impairment in executive functioning, weak central coherence - problem in integrating information in meaningful wholes, impaired empathy. Further, it is very important hearing screening especially if the child manifests some language delay.

It is clear that deviations in the development can appear in different areas. For example, children with mental retardation or autistic spectrum disorders, have usually normal motor skills and delayed language development. Conversely, children with cerebral palsy, often display delayed motor skills with normal language function. At this point it must 
be noticed that regression, the loss of developmental skills, are very serious developmental problems suggestive of an active, ongoing neurologic problem. In the past three years we assessed only one child with very serious mental regression in short period due to central glioblastoma.

Whether or not screening/surveillance identifies problems, parents always need suggestions about the follow-up at home. As a team comprising neurologist and special educator together with pediatrician, we advise different age-appropriate activities and anticipatory guidance focused on how developmental changes affect health and safety. It is very important to encourage parents to promote their child's language and preacademic/academic development.

The aim of this study is to analyze obtained anamnestic information's during developmental monitoring in our hospital, in order to find out the best way to manage children with some level of developmental delay. Supporting children's healthy development and allowing to arise their full potential is the main purpose of our activity.

\section{METHODOLOGY AND SAMPLE}

The developmental monitoring in 465 children at the age of 12 - 60 months, referred as children with developmental delay according to primary care pediatricians, special educators or family members in the period of 4 years (from January 2016 until the end of 2019) was implemented.

Starting at the time of birth and continuing throughout all childhood, children reach milestones in the way how they play, learn, speak, act, and move. Of course, children development is according to own potential, and it can be difficult to suppose when a child will learn a given skill. However, there is a frame in which one child can rich a special milestone. The assessment of the evaluated sample is done using CDC developmental milestone checklist (Centers for Disease Control and Prevention) for specific ages -12 and 18 months and 2, 3, 4 and 5 years.

To assess behavioral and emotional problems, physicians need information from family and people who see children in their everyday contexts. Parents and parent-surrogates are the primary sources of such information's for all children. That is the reason why we always start with taking very precise history. In this context we analyze information's about:

- family history;
- pregnancy and delivery;

- perinatal period;

- nutrition;

- vaccinations;

- psychomotor development - walking, speaking, toilet control...

- allergy;

- past diseases.

Main object of this work is to show the role of history information's in developmental assessment - the way how they guide us through further work.

\section{RESULTS}

From the analyzed sample of 465 children, $16.13 \%$ (or 75 in absolute number) have same serious illness in family history (like epilepsy, psychiatric problems, diabetes, cardiovascular issues). When this number is divided in age range, the results showed that the positive answer is present in $20 \%$ of children (or 10 in absolute number) in first year; in the second year this percent is $29.62 \%$ of children (or 40 in absolute number); $15.79 \%$ of children (or 15 in absolute number) for children in third year; $7.69 \%$ (or 5 in absolute number) in fourth year and $10 \%$ (or 5 in absolute number) in fifth year (Fig 2).

Family history

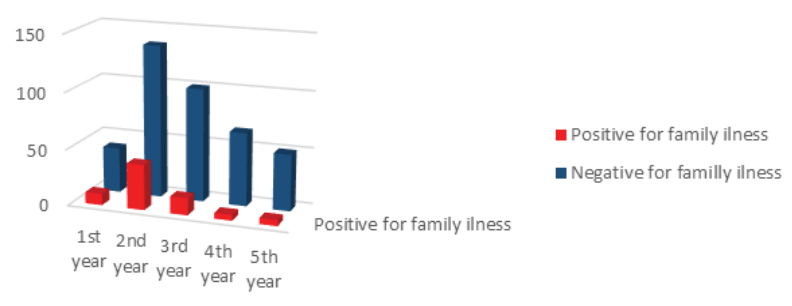

Fig. 2. Results obtained for family history

(number of children with positive family history marked with red and number of children with no serious illness in family history marked as blue in all 5 age groups)

The data for pathological pregnancy are shown in Fig 3. From total 465 children 26,88\% (or 125 in absolute number) were born after pathological pregnancy and most of them after in vitro fertilization. When age range was divided, the results are as follows: $40 \%$ of children (or 20 in absolute number) in 
the first year; $28.57 \%$ of children (or 50 in absolute number) in the second year; $26.09 \%$ of children (or 30 in absolute number) in the third year; $21.43 \%$ (or 15 in absolute number) in the fourth year, and 18.18 $\%$ (or 10 in absolute number) in the fifth year.

Personal history

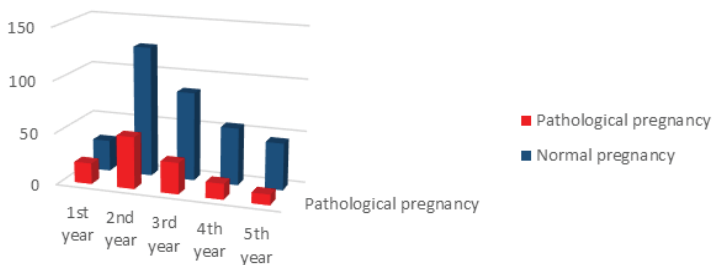

Fig. 3. Results for personal history

(pathological pregnancy is marked with red and normal pregnancy is marked as blue for all 5 age groups)

Manifestations of some problems in the perinatal period are also important. The analysis shows that $16.13 \%$ (or 75 in absolute number) manifested some serious perinatal problems which need support in NICU (neonatal intensive care unit). The age range division shows that pathological pregnancy was detected in $10 \%$ of children (or 5 in absolute number) in the first year; $20 \%$ of children (or 35 in absolute number) in the second year; $21.74 \%$ of children (or 25 in absolute number) in the third year; $7.14 \%$ (or 5 in absolute number) in fourth year and $9.09 \%$ (or 5 in absolute number) in the fifth year (fig. 4).

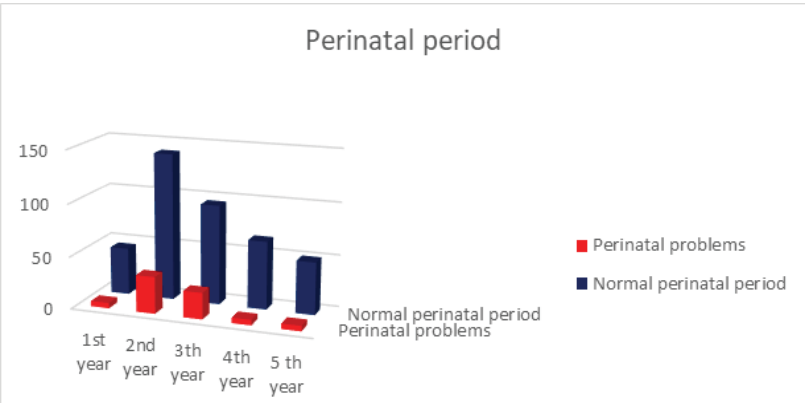

Fig. 4. Problems manifested in the perinatal period (number of children with perinatal problems are marked with red and number of children with normal perinatal period is marked as blue in all 5 age groups)

Research shows that information about feeding are important for the future development.
Our analysis shows that $49.46 \%$ (or 230 in absolute number) were breastfeed. When we divide this number in age range the results are as follows: $20 \%$ of children (or 10 in absolute number) were breastfed in the first year; $57.14 \%$ of children (or 100 in absolute number) in the second year; 47,83 $\%$ of children (or 55 in absolute number) in the third year; $50 \%$ (or 35 in absolute number) in the fourth year and $54,54 \%$ (or 30 in absolute number) in the fifth year (Fig.5).

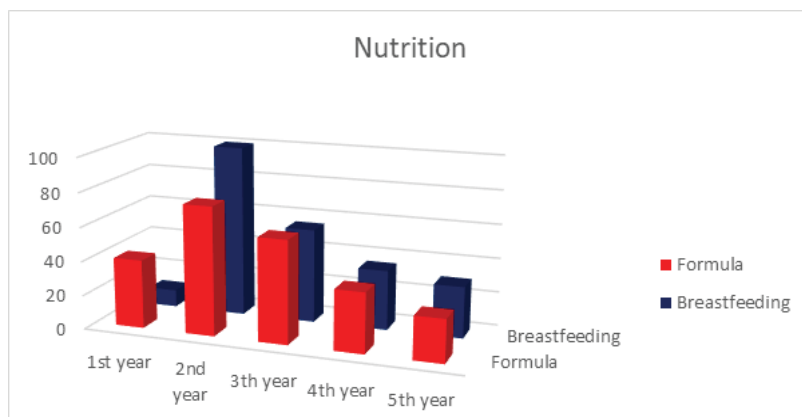

\section{Fig. 5. Nutrition and breastfeeding}

(children on formula are marked with red and children who were breastfed are marked as blue in all 5 age groups)

The vaccination's calendar is now compromised in many regions of the world, including our own. However, obtained data showed that only $7,53 \%$ (or 35 in absolute number) are not completely vaccinated. When we divide this number in age range the results are as follows: there was no unvaccinated child in first year; $8.57 \%$ of children (or 15 in absolute number) were not vaccinated in the second year; $8.69 \%$ of children (or 10 in absolute number) in the third year; $7.14 \%$ (or 5 in absolute number) in the fourth year and $9.09 \%$ (or 5 in absolute number) in fifth year (Fig. 6).

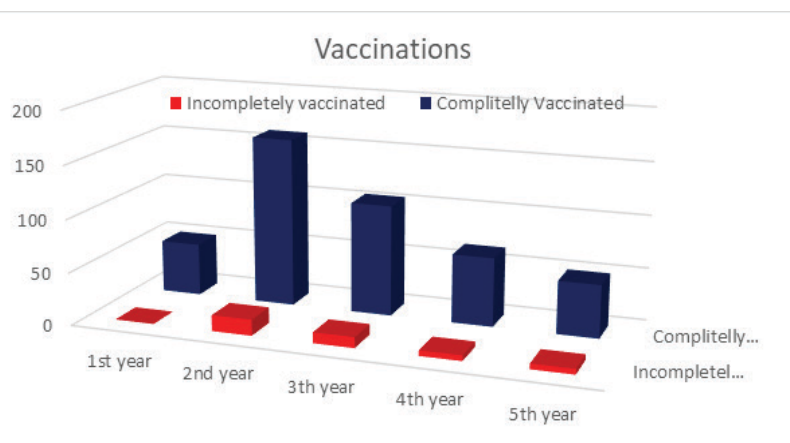

Fig. 6. Data obtained for vaccinations

(children not completely vaccinated are marked with red and children who were completely vaccinated are marked as blue in all 5 age groups) 
In the following, obtained data for personal characteristics of the development presented by the parents are shown. For the parameter walking, we obtained that $11.83 \%$ (or 55 in absolute number) were not walking at the time when the assessment was done. Following age range the results show that $60 \%$ of children were no walking (or 30 in absolute number) in the first year; $8.57 \%$ of children (or 15 in absolute number) in the second year; $4.35 \%$ of children (or 5 in absolute number) in the third year; all analyzed children in fourth year were walking but $9.09 \%$ (or 5 in absolute number) are not walking in the fifth year (Fig. 7).

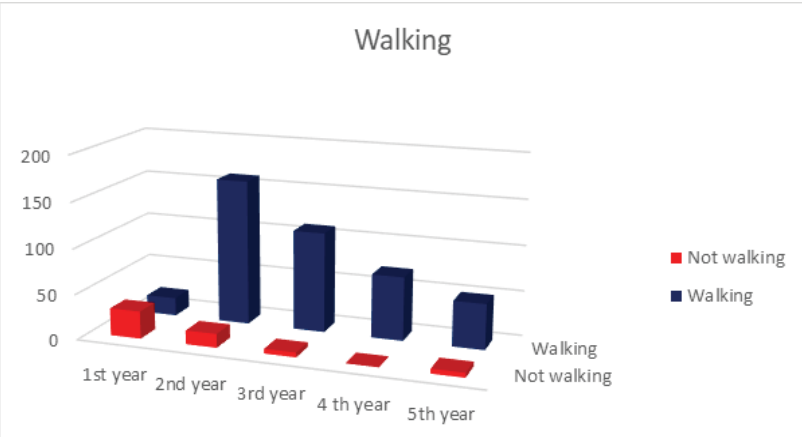

Fig. 7. Motor achievement

(children who don't walk are marked with red and children who are walking is marked as blue in all 5 age groups)

The data obtained for language in the evaluated sample show that $65.81 \%$ (or 306 in absolute number) were not speaking at the time when we make the assessment. Dividing this number in age range show that $90 \%$ of children were no speaking (or 45 in absolute number) in the first year; $92 \%$ of children (or 161 in absolute number) in the second year; $43.48 \%$ of children (or 50 in absolute number) in the third year; $35.71 \%$ of children (or 25 in absolute number) in the fourth year and $45.45 \%$ (or 25 in absolute number) in the fifth year (Fig 8).

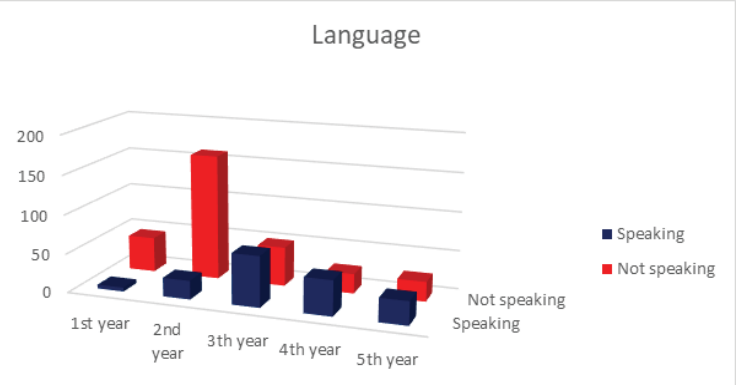

Fig. 8. Language achievements

(children who don't speak are marked with red and children who were speaking are marked as blue in all 5 age groups)
Toilet habits are also one of the indicators for the general development. Our results showed that $75.27 \%$ (or 350 in absolute number) were still wearing diapers and without toilet control at the time when the assessment was done. Age range division shows that $100 \%$ of children don't have toilet control (or 50 in absolute number) in the first year; 100 $\%$ of children (or 175 in absolute number) in the second year; $78.26 \%$ of children (or 90 in absolute number) in the third year; $42.86 \%$ of children (or 30 in absolute number) in the fourth year and $9.09 \%$ (or 5 in absolute number) in the fifth year (Fig 9).

Toilet control

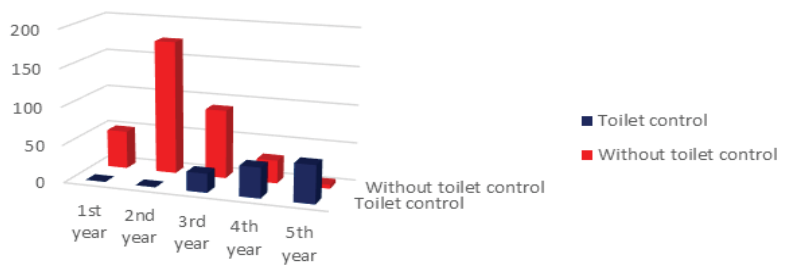

Fig. 9. Toilet control

(number of children without toilet control is marked with red and number of children who achieved toilet control is marked as blue in all 5 age groups)

Predisposition for allergy is very often positive in contemporary history. Our data showed that $8.60 \%$ (or 40 in absolute number) have same allergic manifestations at the time of the assessment. Division in age range shows that $10 \%$ of children have allergy episode (or 5 in absolute number) in the first year; $8.57 \%$ of children (or 15 in absolute number) in the second year; $13.04 \%$ of children (or 15 in absolute number) in the third year; $7.14 \%$ of children (or 5 in absolute number) in the fourth year and nobody among analyzed fifth year (Fig. 10).

Allergy in anamnesis

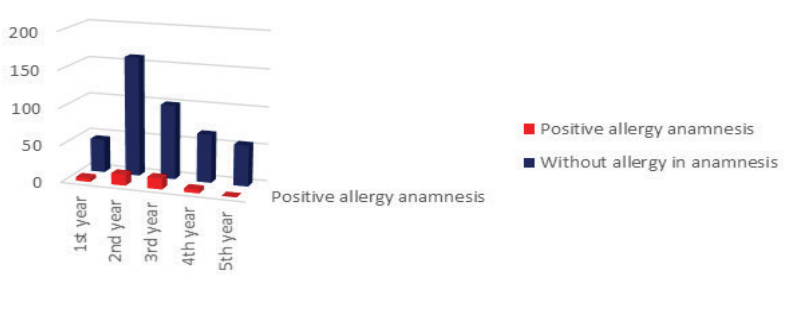

Fig. 10. Allergy in anamnesis

(number of children who have some allergic manifestations is marked with red and number of children who do not have any allergy is marked as blue in all 5 age groups) 
Finally, parents were asked for serious illness in child past history. Positive answers are obtained in $19.35 \%$ (or 90 in absolute number). After age range division, results showed that $10 \%$ of children had episode of serious illness in past (or 5 in absolute number) in the first year; $17.14 \%$ of children (or 30 in absolute number) in the second year; $21.74 \%$ of children (or 25 in absolute number) in the third year; $21.43 \%$ of children (or 15 in absolute number) in the fourth year and $27.27 \%$ (or 15 in absolute number) in the fifth year (Fig.11).

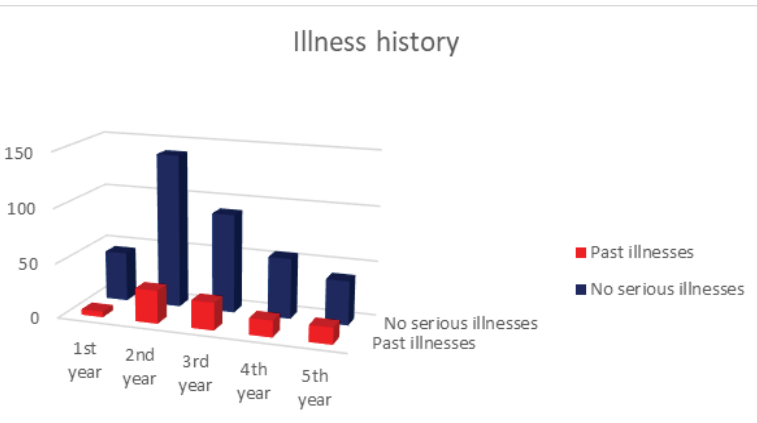

Fig. 11. Illness history

(number of children who have serious diseases in past history is marked with red and number of children who do not have serious diseases is marked as blue in all 5 age groups)

\section{DISCUSSION}

The detection of developmental disorders is an integral component of the well-child care. The term "developmental delay" is used for conditions in which a child is not developing and achieving skills according to the expected time frame.

Parent's concerns about their child's development are usually right. This work analyses anamnestic information's obtained by parents - the way how they understand family history, pregnancy, perinatal period, nutrition etc.

Starting with the family history is the rule. Obtained data in our research showed that only $16.13 \%$ of all analyzed children have anamnestic serious family illness. This is very important information for all pediatricians. Wendy S. Meschino [6] pointed that "the evaluation of the developmentally delayed child should include a detailed history and physical examination, taking special care to record a three-generation pedigree, as well as to look for dysmorphic features". The analysis of distribution through years, shows that in the first group of children, aged one year, $20 \%$ have positive family history for illnesses. Nearly the same percentage was obtained for the group of two years old children $-22.85 \%$. This percentage was much smaller in other three groups - 13,04\% for children three years old, 7,14\% in children 4 years old and $9,09 \%$ in five years old children. It was very difficult to find the reason for this result. Probably, parents are not so motivated to tell about family history, especially if they passed many examinations and no connection was found with previous family history. Sometimes, we must be aware about ethical challenges of parents and tensions between the privacy right and the duty to inform pediatrician about some medical problem in the family. A targeted family history may provide considerable value when a patient presented symptoms that suggest an underlying genetic condition in the family [7]. We usually encourage all parents to think carefully about any illness in family that can be important for the actual state of their child which could help to the appropriate diagnosis.

The analysis of the percentage of children born after pathological pregnancy shows much bigger positive results (26,88\%). More precisely, 125 of all analyzed children in absolute number, were born after pathological pregnancy and most of them after in vitro fertilization. The percentage was the biggest (40\%) in the group of analyzed 12 months old children. This percentage is falling down as age of analyzed children goes up. Maybe, the answer is that parents unconsciously forgot to tell some important facts about pregnancy in most of the cases. Many parents in the group of 4- and 5 -years old children were so much disappointed that did not notice some very important information like mother's HTA during pregnancy. In some situations, they try to hide the fact that the child was born after in vitro fertilization. This is due to the mentality of our people, unfortunately. Opposite, we must know that facts like IVF or pathological pregnancy are very important for pediatrician. Maybe it is very difficult to change this state, but it will save money and time if doctor is trying to find out the reason for the developmental delay. Of course, data for positive pathological pregnancy of mother imply very careful developmental assessment of the child. In some studies, high-risk pregnancy variables showed a significant correlation with developmental delay. Moreover, a significant correlation was observed between high-risk pregnancy and fine motor developmental delay (8). This is much more inves- 
tigated from the aspect of preterm delivery. In the study of Jorien M. Kerstjens and colleagues (2013) results confirmed that from all the preexisting maternal and pregnancy related factors studied, only SGA, maternal pre pregnancy obesity, multiple fetuses, and male sex were associated with the risk of developmental delay in early childhood after moderately preterm birth [9]. In our study 10 percentage of all analyzed children were pre-term babies, while $20 \%$ of them were born as SGA. We could not find any association between maternal pre pregnancy obesity because we did not receive such information. However, $60 \%$ of analyzed pre-term babies were male.

In the article from Terry Levine [10] conclusion was that children are at risk for poorer neurodevelopmental outcomes following intrauterine growth restriction (IUGR), in the period from 6 months to 3 years of age. The heterogeneity of primary outcomes, assessment measures, adjustment for confounding variables, and definitions of IUGR limits synthesis and interpretation. We have the same problem: we receive children followed in other settings and, for example, presented in our hospital for the first time at the age of 4 . It is very difficult to restore all information about their progress and all needed physical measurements. However, IUGR is the factor which is most explored. For example, Thomaidis and colleagues [11] found that specific prenatal and perinatal factors related to disordered neonatal brain function, such as prematurity and IUGR, may be significant and independent predictors of the severity of global developmental delay in cases without definitive etiologic yield. But there are many other aspects of problems during pregnancy. The article of Antonow-Schlorke et al. in Proceedings of the National Academy of Sciences of the United States of America [12], shows that the developing brain is more vulnerable than previously thought, even to moderate reductions in maternal nutrition during early pregnancy. Unfortunately, we never ask mother for her own nutrition during pregnancy. It is very good idea, and having this information we will change some questions in our algorithm. However, we put mandatory question about mother's nutrition during pregnancy and about mother weight during pregnancy.

Something which is even more interesting is maternal stress experience during pregnancy. Babenko and colleagues [13] found that stressful experiences in utero or during early life may increase the risk for neurological and psychiatric disorders, arguably via altered epigenetic regulation. Epigenetic mechanisms, such as miRNA expression, DNA methylation, and histone modifications are prone to changes in response to stressful experiences and hostile environmental factors. The consideration of ancestral and prenatal stress effects on lifetime health trajectories is critical for improving strategies that support healthy development and successful aging. Even if there are many proofs about influence od mother's stress, it is really difficult to explain it in every day work, especially if we know that this can have many implications on family life and interfamily relations.

Additionally, Valla et al. in a study of Developmental Delay in Norwegian infants between 4 and 12 months look for association between mother's education level and suspected developmental delay and did not find any significant association [14]. Many other factors, such as teratogenic drugs, radiation, and vaginal bleeding, were also highlighted as risk factors for infants' developmental delay through their contribution in causing asphyxia and injuries to the developing brain [15]. If we want to identify risk factors during pregnancy the list is too long and as it looks now never ending.

The analyze of the perinatal period shows that again $16,13 \%$ of all children have serious perinatal problems which implicated the treatment in Intensive care units for parenteral therapy and especially complex breathing problems, like transient tachypnea, respiratory distress syndrome, asphyxia, meconium aspiration, pneumothorax, pneumonia and other congenital malformations. It is especially important for the period of hypoxia which can result in some degree of brain damage. In our evaluated group we found very different percentage in different age groups. Very similar was the percentage in group of children 2 and 3 years old and it was around $20 \%$. In the group of patients at the age of 4 and 5 years this percentage was much smaller. We are not sure that this is real. Again, we think that parents exhausted from many examinations passed during looking for help for their child forgot many important details connected to early perinatal period. This is reason why we usually ask parents to bring us documents from hospital. Many of them don't have such documents, especially when children are at the age 4 and 5 years. Some of them (around $25 \%$ of all) even if they have documents they never ask doctors for explanation what the written means. Primarily, we thought that this is in direct 
connection with educational level of patients, but the truth is that even high educated parents not always read examination letter and do not understand what is there written.

Zivanit Ergas [16] in his article about perinatal and early postnatal factors underlying developmental delay and disabilities wrote: "A delay in meeting developmental milestones may be secondary to perinatal events, involving complicated interactions between mother and fetus during delivery. Maternal factors including weight, diet, and morbidities can affect neonatal adaptation and later development. Prematurity, low birth weight, and previous intrauterine insults as well as complications during delivery of a previously normal fetus increase the risk for perinatal stress". Many authors have the same opinion including Thomaidis L. and colleagues who concluded that factors known to be associated with disordered neonatal brain function, such as prematurity, multiple gestation, IUGR, hypertensive disease of pregnancy, birth asphyxia, and neonatal hypoxia, were all associated with lower developmental score [11].

We obtained result that $50,53 \%$ of children were fed with formula. This information is very important having in mind protective effect of breastfeeding on general child's health as well as and from the emotional aspect that breastfeeding promote mother - child relation. However, nearly half of all analyzed children were breastfed. This is not so good percentage, but we must be aware about the fact that children who stay at NICU are at higher risk that their mothers will not have enough milk for breastfeeding. First of all, about stress induced by child's condition and second, because there is not direct stimulation that child makes during sucking at the breast milk production. Unfortunately, modern way of living where most of mother's work is another reason for low percentage of breastfed children especially in families where mother's salary is bigger than fathers one and they stay very short time at home after delivery.

Marzena Drozd-Dabrowska [17] confirmed that breastfeeding was related to lower risk of developmental delay in surveyed children, with similar results published by others. Additionally, breastfeeding was reported as an independent effect in relation to the developmental status at the 12th month of life [18]. At this moment it is very difficult to answer why breastfed children have lower percentage of developmental delay.
Are there one or more factors in mother's milk which somehow is protective, or is this result of emotional effect of breastfeeding on child's development. In this context, Turck D. [19] stated that breastfeeding is associated with slightly enhanced performance on tests of cognitive development. There are other studies about correlation between breastfeeding and developmental milestones. For example, Sacker and colleagues [20] found that infants who had never been breastfed were 50\% more likely to have gross motor coordination delays than infants who had been breastfed exclusively for at least four months.

We were very surprised about the small percentage of unvaccinated children (only 7,53\%), if we know that we live in period of very strong anti-vaccine movement. At the end of the first year there was practically no unvaccinated children. This was expected, especially if we know that the biggest resistance provokes the MMR vaccine, which according our calendar is given at 13 months of the age. The percentage of unvaccinated children in the other age groups is between 7-9\%. Is this the result of trust that patients have in our doctors or is this result of epidemic of measles that we have 2019 and fear from illness? This is however another theme for discussion.

Resistance to vaccination process as a problem for long time. For example, Roberts and Harford in 2002 wrote that possible connections between immunization and developmental disorders, most notably autistic disorders, have been the subject of a great debate and have caused much concern for parents who want to make the safest choices for their children [21]. Furthermore, Mrozek-Budzyn D. in 2013 summarize that the results suggest that there is no relationship between MMR exposure and children's cognitive development. Furthermore, she concludes that the safety of triple MMR is the same as the single measles vaccine with respect to cognitive development [22]. In the article of Smeeth and colleagues published in Lancet (2004) author's findings suggest that MMR vaccination is not associated with an increased risk of pervasive developmental disorders [23]. The list of articles which present no connection between vaccination and developmental delay is very long. As professionals, from the same beginning we knew that vaccination is safe, but it was very difficult to persuade the parents about this, especially because of very strong anti-vaccine movement in social media. 
The next very important anamnestic question in our survey is about psychomotor development. Answers showed that $11,83 \%$ do not walk at the time of our first assessment. When we divide this in age range, the results are as follows: $60 \%$ of children were no walking (or 30 in absolute number) in the first year; $8,57 \%$ of children (or 15 in absolute number) in the second year; 4,35\% of children (or 5 in absolute number) in the third year; all analyzed children in fourth year were walking and, $9.09 \%$ (or 5 in absolute number) do not walk in the fifth year.

Normally, children start walking around the first birthday. So, we should not be too concerned about the results that we received for children 12 months old. But in older groups motor delay is present between 4-9\% of all analyzed sample. Usually, motor delay is a part of global developmental delay and has been explored in many clinical trials. In a study of Provost and colleagues [24] the comparison of motor delays in young children with Autism Spectrum Disorder, developmental delay and suspected developmental delay, were made. The results show that the motor scores of young children with ASD did not differ significantly from those of young children with development delay. Anyway, motor delay must be very careful assessed always. In this context, Lei Wang and colleagues who assessed 3353 rural children, showed that $49 \%$ of the children have cognitive delays, $52 \%$ have language delays, $53 \%$ have social-emotional delays, and 30\% have motor delays [25].

The importance of the motor delay must never be denied. In this direction, the estimations, based on proxy measures of stunting and poverty, indicated that 250 million children (43\%) younger than 5 years in low-income and middle-income countries are at risk of not reaching their developmental potential [26]. Even more, it is very important to assess very carefully these children in order to find if motor delay is suggestive of an active, ongoing neurologic problem. Our conclusion is that when motor delay is present, we must be very consistent in medical examination trying to find reason for neurologic impairment.

In our evaluated sample $65,81 \%$ of children do not speak at the time during the first assessment, although in some children from older groups (three to five years) speech therapy was started. Our findings are corresponding to the findings of other authors which evidence implies that untreated speech and language delay can persist in
$40 \%-60 \%$ of the children and these children are at a higher risk of social, emotional, behavioral, and cognitive problems in adulthood [27, 28]. In general, language impairments affect $7 \%$ of preschool children [29]. Most concerning is the fact that $16 \%$ of children with expressive language delays at age 2 continued to present with language impairments at the age of 7 [30]. Additionally, children in whom speech and language impairments persist during 5 and half years of age have an increased incidence of attention and social difficulties [31].

Why is this so important? If children do not reach the expected milestones for speech and language, a comprehensive developmental evaluation is essential, because atypical language development can be a secondary characteristic for other physical and developmental problems that may be first manifested as language problems. Types of primary speech and language delay include developmental speech and language delay, expressive language disorder, and receptive language disorder. Secondary speech and language delays are attributable to another condition such as hearing loss, intellectual disability, autism spectrum disorder, physical speech problems, or selective mutism [32]. Most of the parents suppose that their children have just delay in speech and everything else is completely normal. They did not make a difference between not speaking and not understanding the speech. In our group between $10-15 \%$ of children who did not speak or speak only few words, understand nearly everything and have normal social communication with family. Rest of them have language delay as a part of global developmental delay.

Toilet control is a part of psychomotor development. Very disappointed was our obtained results that $75,27 \%$ do not achieve toilet control at the time of first assessment. The results were even more concerning if we divide the patient in groups. All $100 \%$ of children old 2 years do not reach toilet control at the time of assessment, $78.26 \%$ of children (or 90 in absolute number) in the third year, $42.86 \%$ of children (or 30 in absolute number) in the fourth year and $9.09 \%$ (or 5 in absolute number) in the fifth year. For the vast majority of typically developing children in the United States, 98\%, have completely toilet control by their third birthday [33]. Even for individuals without developmental disabilities, toilet training can be a difficult developmental milestone. This requires time, energy, and patience of parents, which is very rare in modern pattern of living. 
Most of the parents are exhausted, without free time and diapers are ideal solution. Today, nearly all children without developmental disabilities are successfully toilet trained by age 3 . In contrast, individuals with developmental disabilities face greater obstacles with toilet training than typically developing peers, based on their behavior impairments. If the child with developmental delay goes to kindergarten, toilet control requires a graded and child-specific mediation process, including the parents and the educational staff [34]. Because each family and child are unique, recommendations about the ideal time or optimal method must be customized. Family physicians should provide guidance about toilet-training methods and identify children who have difficulty reaching developmental milestones [35]. The American Association of Pediatricians (AAP) strongly recommends that children do not be forced to start training until they are not behaviorally, emotionally, and developmentally ready.

Allergies occur as a result of an overreaction of the immune system. Normally, the immune system protects the body from invaders such as viruses and bacteria that can cause illness. People with allergies have an immune system that reacts to a harmless substance as though it was harmful. Allergic conditions, including respiratory allergy, skin allergy, and food allergy, are common medical conditions of immunologic dysfunction in children (36). That's why in the regular anamnestic assessment of children we ask for predisposition for allergy. In our sample $8,40 \%$ of children have positive allergic manifestation in the time of assessment. Percentage was the biggest $(13,04 \%)$ in the group of the children aged 3 years. At this point, it is very difficult to compare our results with any other study just because of the very big differences in analyzed sample, kind of allergy and fact that this is just anamnestic information which might not be try. Anyway, our interest about this condition was according to novel researches and works which try to make connection between immune response and brain development. In this context, we would like to quote Staci D. Bilbo and Jaclyn M. Schwarz who said: "The brain, endocrine, and immune systems are inextricably linked. Immune molecules have a powerful impact on neuroendocrine function, including hormone-behavior interactions, during health as well as sickness. The developing brain in particular is exquisitely sensitive to both endogenous and exogenous signals, and increasing evidence suggests the immune system has a critical role in brain development and associated behavioral outcomes for the life of the individual" [37].

Honestly, most of the works in this field are made by authors who investigate ASD, like Guifeng Xu and colleagues [38]. Based on nationally representative data in large cross-sectional surveys, they found a significant and positive association between common allergic conditions, especially food allergy, and ASD in US children. Very similar is the work of de Theije CG and colleagues (39) who concluded that allergic immune reactions, in prenatal and postnatal phases, are examples of environmental factors, and adverse reactions to foods in children with ADHD and ASD.

Finally, we asked parents for serious illness in personal child history. From the analyzed 465 children $19.35 \%$ (or 90 in absolute number) have episode of serious illness in the past, in the time of assessment. When we divide this in age range the results are $-10 \%$ of children have episode of serious illness (or 5 in absolute number) in the first year. All of them have perinatal problems and need treatment at NICU. If we exclude perinatal problems, no serious illness was detected in group of children aged 12 months. In the second year, the percentage is $17.14 \%$ (or 30 in absolute number); $21.74 \%$ (or 25 in absolute number) in the third year; $21.43 \%$ of children (or 15 in absolute number) in the fourth year and 27.27 $\%$ (or 15 in absolute number) in the fifth year. Anyway, it is very difficult to analyze this fact because there is very big discrepancy between parent's meaning of serious illness. Some of them did not mention infection like pneumonia, even the child was hospitalized for this condition. The other report confirmatory for very serious illness show that the child has upper respiratory tract infection which need just antibiotic therapy. Unfortunately, parents in very small number bring medical documents which could be confirmative for finding connection between serious illness in the past and developmental delay.

\section{CONCLUSIONS}

Good history is a half of diagnosis, is the confirmed rule in medicine. A good history helps to direct further investigation, particularly when exogenous causes are identified.

Data for preexisting maternal and pregnancy related factors like IVF, maternal HTA and 
pre-pregnancy obesity, poor maternal nutrition, mothers stress experience, teratogenic drugs, radiation, vaginal bleeding, could be risk factors of infants' developmental delay causing asphyxia and injuries to the developing brain.

In the perinatal period all serious perinatal problems which need treatment in Intensive care units must be taken into account.

Information about early child's nutrition is very important from the aspect of protective effect of breastfeeding on general child's health and from the emotional aspect that breastfeeding promote mother - child relation.

Resistance to vaccination as a long-lasting problem seems to be overcome.

Motor delay is suggestive for an active, ongoing neurologic problem. When motor delay is present, medical examination must try to find some neurologic impairment.

The most marked anamnestic problem is speech and language delay. It is very important to recognize specific language impairment and separate it from global developmental delay where atypical language development can be a secondary characteristic of other physical and developmental problems that may first manifest as language problems.

Toilet control is a part of psychomotor development. It is strongly recommended that children not to be forced to start training until they are not behaviorally, emotionally, and developmentally ready.

Immune system has a critical role in brain development and associated behavioral outcomes. Immune molecules have a powerful impact on neuroendocrine function, including hormone-behavior interactions, during health as well as sickness. In this context, allergies occur as a result of an overreaction of the immune system and must be notified in history.

\section{REFERENCES}

1. Council on Children with Disabilities, Section on Developmental Behavioral Pediatrics, Bright Futures Steering Committee, and Medical Home Initiatives for Children with Special Needs Project Advisory Committee (Policy Statement of AAP). Identifying infants and young children with developmental disorders in the medical home: an algo- rithm for developmental surveillance and screening. Pediatrics. 2006; 118(1): 405-420.

2. Data Resource Center is a project of the Child and Adolescent Health Measurement Initiative at Oregon Health \& Science University and is sponsored by the Maternal and Child Health Bureau, Health Resources and Services Administration. (2011/2012).

3. Boyle C, Boulet S, Schieve L., et al. Trends in the Prevalence of Developmental Disabilities in US Children, 1997-2008, Pediatrics (2011), online, 1034-1042.

4. Glascoe F. Are over-referrals on developmental screening tests really a problem? Archives of Pediatric Adolescent Medicine (2001), 155(1): 54-9.

5. King TM, Rosenberg LA, Fuddy L, et al. Prevalence and early identification of language delays among at-risk three year olds. J Dev Behav Pediatr. 2005; 26: 293-303.

6. Wendy S Meschino. The child with developmental delay: An approach to etiology. Paediatr Child Health. January 2003; Vol. 8 No 1.

7. Trotter TL, Martin HM. Family history in pediatric primary care. Pediatrics. 2007; 120 (suppl 2): S 62.

8. Torabi F, Amir S, Akbari A at all. Correlation between high-risk pregnancy and developmental delay in children aged 460 months. Libyan J Med 2012, 7: 18811.

9. Kerstjens JM, de Winter AF, Sollie KM et all. Maternal and Pregnancy-Related Factors Associated with Developmental Delay in Moderately Preterm-Born Children. OBSTETRICS \& GYNECOLOGY. Vol. 121, No. 4, April 2013.

10. Levine TA, Grunau RE, McAuliffe FM at all. Early Childhood Neurodevelopment After Intrauterine Growth Restriction: A Systematic Review. Pediatrics January 2015; 135 (1): 126-141.

11. Thomaidis L, Zantopoulos GZ, Fouzas S et al. Predictors of severity and outcome of global developmental delay without definitive etiologic yield: a prospective observational study. BMC Pediatrics 2014; 14: 40.

12. Antonow-Schlorke I, Schwab M, Cox LA, et al. Vulnerability of the fetal primate brain to moderate reduction in maternal global nutrient availability. Proc Natl Acad Sci USA 2011; 108: 3011-3016.

13. Babenko O, Kovalchuk I, Metz GA. Stress-induced perinatal and transgenerational epigenetic programming of brain development and mental health. Neurosci Biobehav Rev. 2015 Jan; 48: 70-91.

14. Vela, H.C.; Martinez, M.F.; Guzman, I.B. Characteristics of visual evoked potentials in infants who had severe neonatal hyperbilirubinemia. Clin. Neurophysiol. 2016; 127: e317

15. Ziviani J, Feeney R, Rodger S et al. Systematic review of early intervention programmes for chil- 
dren from birth to nine years who have a physical disability. Austral. Occup. Ther. J. 2010; 57: 210-223.

16. Ergaz Z, Ornoy A. Perinatal and Early Postnatal Factors Underlying Developmental Delay and Disabilities. Special Issue: Developmental Delay. Volume17, Issue2. November 2011: 59-70.

17. Drozd-Dabrowska M, Trusewicz R, Ganczak M. Selected Risk Factors of Developmental Delay in Polish Infants: A Case-Control Study. Int. J. Environ. Res. Public Health 2018; 15: 2715.

18. Oberhelman RA, Guerrero ES, Fernandez ML et al. Correlations between intestinal parasitosis, physical growth, and psychomotor development among infants and children from rural Nicaragua. Am. J. Trop. Med. Hyg. 1998, 58: 470-475.

19. Turck D; Comité de nutrition de la Société française de pédiatrie. Breast feeding: health benefits for child and mother. Arch Pediatr. 2005 Dec; 12 Suppl 3 : S145-65. Epub 2005 Nov 21. Review.

20. Sacker A, Quigley MA, Kelly YJ. Breastfeeding and developmental delay: Findings from the millennium cohort study. Pediatrics 2006, 118: 682689.

21. Roberts W, Harford M. Immunization and children at risk for autism. Paediatr Child Health 2002; 7(9): 623-632.

22. Mrozek-Budzyn D, Kieltyka A, Majewskaat R al. Measles, mumps and rubella (MMR) vaccination has no effect on cognitive development in children - the results of the Polish prospective cohort study. Vaccine. 2013 May 24; 31(22): 2551-2557.

23. Smeeth L, Cook C, Fombonne E et all. MMR vaccination and pervasive developmental disorders: a case-control study. Lancet. 2004 Sep 11-17; 364(9438): 963-9.

24. Provost B, Lopez BR, Heimerl. A Comparison of Motor Delays in Young Children: Autism Spectrum Disorder, Developmental Delay, and Developmental Concerns. J Autism Dev Disord (2007) 37: 321-328).

25. Wang L, Liang W, Zhang S at al. Are infant/toddler developmental delays a problem across rural China? Journal of Comparative Economics 47 (2019): 458-469.

26. Black MM Walker SP, Lia C H Fernald LCH et al. Advancing Early Childhood Development: from Science to Scale 1.Early childhood development coming of age: science through the life course. Lancet. 2017 Jan 7; 389(10064): 77-90.

27. Law J, Rush R, Schoon L et al. Modeling developmental language difficulties from school entry into adulthood: Literacy mental health and employment outcomes. J Speech Lang Hear Res. 2009; 52: 1401-16.;

28. Morgans A, Ttofari Eecen K, Pezic A et al. Who to refer for speech therapy at 4 years of age versus who to watch and wait. J Pediatr. 2017; 185: 200-4.

29. Ziegler JC, Pech-Georgel C, George F et al. Deficits in speech perception predict language learning impairment. Proceedings of the National Academy of Sciences of the United States of America, (2005, September 27). 102(3a): 14110-14115.

30. Paul R. Predicting outcomes of early expressive language delay: ethical implications. In: Bishop DVM, Leonard L.B., eds. Speech and language impairments in children: causes, characteristics, intervention and outcome. Philadelphia: (2000). Psychology Press, 195-209.

31. Snowling MJ, Bishop DV, Stothard SE et al. Psychosocial outcomes at 15 years of children with a preschool history of speech language impairment. J Child Psychol Psychiatry. 2006; 47(8): 759-765.

32. Mc Laughlin M.R. Speech and Language Delay in Children. American Family Physician May 15, 2011; Volume 83, Number 10.

33. Blum NJ, Taubman B, Nemeth N. Relationship between age at initiation of toilet training and duration of training: A prospective study. Pediatrics, 2003; 111: 810-814.

34. Shoshani S, Schreuer N. Toilet training of preschoolers with disabilities: The perspectives of teacher aides. May 2019. Neurourology and Urodynamics: 38(2).

35. Choby BA, George S. Toilet Training. American Family Physician. 2008; 78(9): 1059-1064, 1066.

36. Jackson KD, Howie LD, Akinbami LJ. Trends in allergic conditions among children: United States, 1997-2011. NCHS Data Brief. 2013; 121(121): $1-8$.

37. Bilbo SD, Schwarz JM. The Immune System and Developmental Programming of Brain and Behavior. Front Neuroendocrinol . 2012 August; 33(3): 267-286.).

38. Guifeng Xu, Snetselaar LG, Jing J. et al. Association of Food Allergy and Other Allergic Conditions With Autism Spectrum Disorder in Children. JAMA Netw Open. 2018 Jun; 1(2): e180279.

39. de Theije CG, Bavelaar BM, Lopes da Silva Set al. Food allergy and food-based therapies in neurodevelopmental disorders. Pediatr Allergy Immunol. 2014 May; 25(3): 218-26. 


\title{
Резиме
}

\section{ПОДАТОЦИТЕ ОД ИСТОРИЈАТА СЕ НЕОПХОДНИ ВО ПРОЦЕНА НА РАЗВОЈОТ КАЈ ДЕЦАТА}

\author{
Анета Демершиева ${ }^{1}$ и Нада Поп-Јорданова ${ }^{2}$ \\ ${ }^{1}$ Аџибадем Систина, Скопје, РС Македонија \\ ${ }^{2}$ Македонска академија на науките и уметностите, Скопје, РС Македонија
}

Педијатарот мора да го следи развојот на детето со цел да обезбеди негова благосостојба.

Анализиравме 465 деца на возраст од 12 до 60 месеци во период од четири години (20162019) упатени за развојна процена. Притоа, користевме алгоритам во кој иницијално зедовме анамнестички податоци за децата. Анамнезата мора да биде сеопфатна и да содржи податоци за пренаталниот, перинаталниот и постнаталниот период.

Добиените резултати покажуваат дека 16,13 \% од анализираните пациенти имаат сериозна болест во семејната историја и идентичен процент деца имале перинатални проблеми што наложувале третман на ЕИНТ (единица за интензивна нега и терапија). На прашањето за типот на исхрана, добивме информации дека 49,46 \% биле на мајчино млеко. Само 7,53 \% не биле вакцинирани.

Анализирајќи ги анамнестичките податоци за психомоторниот развој, дојдовме до сознание дека $11,83 \%$ од децата сѐ уште не одат во моментот на првичната процена, а $65,81 \%$ cè уште немаат говор. Поразителни беа информациите за контрола на сфинктерите $-75,27$ \% од децата сѐ уште беа со пелени.

Алергиски манифестации беа нотирани кај 8,60 \%, а сериозна болест во минатото - кај $19,35 \%$ од анализираните пациенти.

Заклучивме дека добрата анамнеза е неопходна во процесот на развојна процена, посебно кога ќе се идентификуваат одредени причинители како ризик-фактор за развојно доцнење. Добиените информации се насоки за продлабочени иследувања, кои би ја потврдиле причинско-последичната врска.

Клучни зборови: развој, деца, процена, анамнеза 